\title{
Radial stem growth in response to microclimate and soil moisture in a drought-prone mixed coniferous forest at an inner Alpine site
}

\author{
Walter Oberhuber • Andreas Gruber • \\ Werner Kofler • Irene Swidrak
}

Received: 16 September 2013/Revised: 6 December 2013/Accepted: 17 December 2013/Published online: 3 January 2014

(C) The Author(s) 2014. This article is published with open access at Springerlink.com

\begin{abstract}
Dendroclimatological studies in a dry inner Alpine environment (750 $\mathrm{m}$ a.s.l.) revealed different growth response of co-occurring coniferous species to climate, which is assumed to be caused by a temporal shift in wood formation among species. The main focus of this study therefore was to monitor intra-annual dynamics of radial increment growth of mature deciduous and evergreen coniferous species (Pinus sylvestris, Larix decidua and Picea abies) during two consecutive years with contrasting climatic conditions. Radial stem growth was continuously followed by band dendrometers and modelled using Gompertz functions to determine time of maximum growth. Histological analyses of tree ring formation allowed determination of temporal dynamics of cambial activity and xylem cell development. Daily fluctuations in stem radius and radial stem increments were extracted from dendrometer traces, and correlations with environmental variables were performed. While a shift in temporal dynamics of radial growth onset and cessation was detected among co-occurring species, intra-annual radial growth peaked synchronously in late May 2011 and early June 2012. Moist atmospheric conditions, i.e. high relative air humidity, low vapour pressure deficit and low air temperature during the main growing period, favoured radial stem increment of all species. Soil water content and soil temperature were not significantly related to radial growth. Although a temporal shift in onset and cessation of wood formation was detected among species, synchronous
\end{abstract}

Communicated by R. Matyssek.

W. Oberhuber $(\bowtie) \cdot$ A. Gruber · W. Kofler · I. Swidrak Institute of Botany, Leopold-Franzens-University of Innsbruck, Sternwartestrasse 15, 6020 Innsbruck, Austria e-mail: Walter.Oberhuber@uibk.ac.at culmination of radial growth indicates homogenous exogenous and/or endogenous control. The close coupling of radial growth to atmospheric conditions points to the importance of stem water status for intra-annual growth of drought-prone conifers.

Keywords Cambial activity · Climate-growth relationship · Conifers · Dendrometer · Drought · Intraannual radial growth

\section{Introduction}

A major factor affecting radial stem growth and wood formation in trees is climatic variation. Climate-growth relationships of trees are frequently determined by applying dendroclimatological techniques (Hughes et al. 2011). Decade-to-century long-time series of radial tree growth (ring width) are related to climate variables (e.g. monthly mean temperature and total precipitation) to determine growth-limiting climatic factors (Fritts 1976). However, radial stem growth, i.e. cambial cell division and cell enlargement, proceeds in woody plants at timescales of hours to a few days and is controlled by environmental factors on a daily timescale (e.g. Köcher et al. 2012). Therefore, a combination of dendroclimatological and intra-annual growth studies is recommended to assess longand short-term climatic influences on tree growth, respectively (Deslauriers et al. 2003a; Rossi et al. 2006b; Gruber et al. 2009). Knowledge of intra-annual dynamics of radial tree growth allows determination of (1) crucial phenological stages of radial growth, i.e. onset, time of maximum growth, end and duration of wood formation, (2) seasonal influence of meteorological factors on growth and (3) species-specific response to climate change (Plomion et al. 
2001; Deslauriers et al. 2003a; Linares et al. 2009; Michelot et al. 2012; Zhai et al. 2012). Fine-scaled histological analyses of radial growth in Pinus sylvestris already revealed that at drought-prone sites, onset and end of radial growth was controlled by air temperature and soil water availability, respectively (e.g. Thabeet et al. 2009; Swidrak et al. 2011).

While histological analyses of wood formation provide a resolution of about 1 week, dendrometers have frequently been used for continuous monitoring of radial stem growth (Dünisch and Bauch 1994; Herzog et al. 1995; Zweifel et al. 2000; Bouriaud et al. 2005). Although dendrometer measurements are known to be strongly influenced by water-related swelling and shrinkage of the bark (Zweifel and Häsler 2000; Daudet et al. 2005), methods were developed to extract radial increment from dendrometer traces (for a review see Deslauriers et al. 2007).

Scots pine ( $P$. sylvestris L.) is usually the dominating tree species at xeric sites in dry inner Alpine valleys; however, it co-occurs with competitor species (European larch, Larix decidua Mill., and Norway spruce, Picea abies (L.) Karst.) at dry-mesic sites. These co-occurring conifers show different successional and phenological traits, whereby evergreen $P$. sylvestris and deciduous $L$. decidua are light-demanding species dominating in early successional stages, while evergreen $P$. abies is a moderately shade-tolerant tree, which predominates in the late-successional stage and is one of the most common tree species in the Alps (Ellenberg and Leuschner 2010). Shade tolerance and shallow rooting were suggested to provide $P$. abies a competitive advantage over more drought-tolerant $P$. sylvestris, enabling the former species to invade mixed stands exposed to drought (Schuster and Oberhuber 2013b). On the other hand, although L. decidua is regarded to be less drought-resistant than $P$. sylvestris (Eilmann and Rigling 2012), Anfodillo et al. (1998) reported that $L$. decidua is very efficient at adapting to drought by osmotic adjustment. Previous dendroclimatological studies on climate-growth relationships of these coniferous forest tree species revealed different growth response to climate (Schuster and Oberhuber 2013a). Authors suggested that competitive strength and sensitivity of radial stem growth to climate is affected by seasonal timing of growth processes, which is supported by findings of Cuny et al. (2012), who reported contrasting intra-annual growth strategies adopted by early- and late-successional conifer species (Abies alba, P. abies, P. sylvestris) grown intermixed in a temperate forest in France.

Consequently, the focus of this study was on determining the influence of environmental variables (climate, soil water content and soil temperature) on intra-annual radial stem growth and cambial phenology of co-occurring early- and late-successional conifers during two contrasting years.
Because several authors found that topography and smallscale variability in edaphic conditions modulate growth response of trees to climate (Orwig and Abrams 1997; Oberhuber and Kofler 2000; Fekedulegen et al. 2003), a mixed-species stand was analysed to determine how environmental conditions affect growth. Based on continuous monitoring of stem radius variation throughout the year, daily changes in stem radius and extracted radial increments were used to determine influence of environmental factors on radial tree growth. While histological analyses of cambial activity and tracheid formation allowed timing of radial growth onset and end, dendrometer records (DMR) were modelled using Gompertz functions (Zeide 1993) to determine time of maximum growth. We hypothesized that different timing of crucial phenological stages of radial stem growth of co-occurring species leads to different growth response to environmental variables.

\section{Materials and methods}

\section{Study area}

The study site is part of a postglacial rock-slide area situated in the montane belt (c. $750 \mathrm{~m}$ a.s.l.) within the inner Alpine dry valley of the Inn River (Tyrol, Austria, $47^{\circ} 13^{\prime} 53^{\prime \prime} \mathrm{N}$, $\left.10^{\circ} 50^{\prime} 51^{\prime \prime} \mathrm{E}\right)$ and has a relatively continental climate with mean annual precipitation and temperature of $716 \mathrm{~mm}$ and $7.3{ }^{\circ} \mathrm{C}$, respectively (long-term mean during 1911-2010 at Ötz, $812 \mathrm{~m}$ a.s.l., $5 \mathrm{~km}$ from the study area). Although the dominating plant community is an open Spring Heath-Pine wood (Erico-Pinetum typicum), on scattered dry-mesic sites, mixed stands composed of $P$. sylvestris $(60 \%), P$. abies $(20 \%)$ and L. decidua (20\%) are developed. At these sites, a thick moss layer occurs in the understorey, indicating slightly moist conditions. Shallow soils of protorendzina type, i.e. rendzic leptosols according to the FAO classification system (FAO 2006), are developed and consist of unconsolidated, coarse-textured materials with low waterholding capacity (soil depth $10-20 \mathrm{~cm}$ ). Tree height and canopy coverage of the selected stand were 15-18 $\mathrm{m}$ and c. $70 \%$, respectively. The study site was partly slightly facing north (slope angle $5^{\circ}$ ). Mean tree age and diameter at breast height ranged from 115 years (P. abies) to 150 years (P. sylvestris, L. decidua) and $23.0 \mathrm{~cm}$ (P. abies) to $27.8 \mathrm{~cm}$ (P. sylvestris, L. decidua), respectively (cf. Schuster and Oberhuber 2013a).

Determination of cambial activity and wood formation

Seasonal wood development was monitored during the growing seasons of 2011 and 2012 by taking small punched cores from eight trees/species of the outermost tree rings 
(microcores) with a diameter and length of $2.5 \mathrm{~mm}$ and $c$. $2 \mathrm{~cm}$, respectively (Rossi et al. 2006a). Individual trees were randomly selected, but trees with major stem or crown anomalies were excluded from the analysis. Microcores were taken from March through October in weekly to 10-day intervals to include. Samples were taken on the slope-parallel side of the stem following a spiral trajectory up the stem starting at $c$. 1-m stem height. A distance of 2-3 cm in tangential and longitudinal direction was kept to avoid lateral influence of wound reactions on adjacent sampling positions. Microcores were sampled from the same dominant trees during both study years.

Immediately after extraction, cores were stored in a microtube with $10 \%$ aqueous ethanol and stored at $5{ }^{\circ} \mathrm{C}$. Subsequently, cores were embedded in glycolmethacrylate (Technovit 7100), polymerized after adding an accelerator, and transverse sections of $c .12 \mu \mathrm{m}$ were cut with a rotary microtome. The number of cambial cells (i.e. fusiform cells lacking radial enlargement) and radialenlarging cells were counted on all sampled cores in three radial rows. Cells in the cambial zone had thin cell walls and small radial diameters. Cells in radial enlargement were larger than cambial cells, and observations under polarized light discriminated between enlarging and birefringent wall-thickening tracheids. Tracheid formation was considered to have begun when one horizontal row of enlarging cells was detected. Intra-annual radial growth was considered to be complete when no more enlarging tracheids were developed. Duration of tracheid formation was delimited by day of the year, when onset and end of cell enlargement was detected. Because cell number varies within the tree circumference, the number of enlarging tracheids was standardized based on the total xylem cell number of the previous tree ring (for details see Gruber et al. 2010).

\section{Dendrometer records}

In autumn 2010, we installed temperature-compensated electronic band dendrometers (DC2, Ecomatik, Munich, Germany) with a resolution of $1 \mu \mathrm{m}$ at six trees per species to measure diurnal radius variation and stem radial growth at breast height. The measuring cable consisted of Invarsteel, which shows a temperature coefficient of linear expansion $<1 \mu \mathrm{m} / \mathrm{mK}$. Dead outermost layers (periderm) of the bark were slightly removed to reduce the influence of hygroscopic swelling and shrinkage of the bark on DMR and to ensure close contact with the stem. Data loggers were programmed to record measurements taken every $30 \mathrm{~min}$, and daily increment of stem radius was calculated by averaging all daily measurements (48 values/day). To avoid influence of frequent wounding on dendrometer traces, different sample populations for determination of wood formation and dendrometer measurements were selected within the same stand.

The daily stem radius variation from late March through end of October was then determined by calculating the difference between mean values of two consecutive days ("daily mean approach", Deslauriers et al. 2007), which represents a combination of reversible shrinking and swelling and irreversible radius growth (Herzog et al. 1995; Daudet et al. 2005; Steppe et al. 2006). Deslauriers et al. (2007) found that the daily mean approach provided results similar to the stem cycle approach. Additionally, we extracted radial stem increments from DMR based on the methodology described by Downes et al. (1999) and Deslauriers et al. (2003b). Radial stem increment was defined as that part of the stem's circadian cycle, when the stem radius exceeded the morning maximum until the subsequent maximum. Only consecutive maximum values were used in correlations between stem increment and environmental variables. When $>3$ days were required until the previous cycle maximum was exceeded, which occasionally was caused by drought-induced reversible shrinking of the stem, the difference between maximum values was allocated to the last 3 days before the maximum was reached.

Determination of the baseline in DMR, i.e. timing of onset of radial growth, can be masked by water-related swelling or shrinkage of the stem caused by stem rehydration after frost-induced shrinkage during winter and stem dehydration during drought periods, respectively (Zweifel and Häsler 2000; Gruber et al. 2009, 2010; Turcotte et al. 2009). While cambial cell division represents only a small amount of radial change and secondary wall thickening and lignification take place inside enlarged cells and therefore are not expressed as a radial increase, tracheid expansion (cell enlargement) is regarded the major driving force for radial stem increase (Deslauriers et al. 2003b). In previous studies, histological analyses of developing tracheids allowed proper timing of radial growth onset in dendrometer traces of conifers exposed to drought (Linares et al. 2009; Oberhuber and Gruber 2010). Similarly, dendrometer traces in this study were set to zero at the day of the year, when first row of enlarging cells was detected.

\section{Statistical analyses}

Short-term variation in intra-annual radial growth was modelled with a Gompertz function using the non-linear regression procedure included in the Origin software package (OriginLab Corporation, Northampton, MA, USA). The Gompertz equation proved its versatility in describing growth-limiting processes (Zeide 1993; Rossi et al. 2003; Deslauriers and Morin 2005). Pearson's 
correlation coefficients were calculated between environmental variables [precipitation, relative air humidity $(\mathrm{RH})$, vapour pressure deficit (VPD), air and soil temperature, soil water content (SWC)] and daily stem radius changes and radial stem increments extracted from DMR. KolmogorovSmirnov tests were applied to check for normal distribution of selected variables. Kendall's rank correlation coefficient ( $\tau$, Sheskin 2007) was determined for not normally distributed environmental variables. Deslauriers et al. (2007) suggested, including only the main period of growth, to assess relationships between environmental variables and dendrometer data. Therefore, to determine climate-growth relationships, only the most linear growth phase during both study years was considered, i.e. correlations were calculated for the period \pm 14 days around the inflection point of the Gompertz model. A time lag of one day was considered for relationships between environmental variables and extracted radial stem increments.

Additionally, principal component analysis (PCA) was used as a clustering technique to determine influence of all environmental variables on stem diameter variations during both study years. PCA is a data reduction technique that transforms the original variables into a set of uncorrelated variables (eigenvectors or principal components) in such a way that the first few components encompass most of the variability in the original variables. Due to strong correlation structure of the data, the number of components retained was determined on the basis of the Kaiser-Guttman criterion (eigenvalues $>1$ ). Specifically, $z$-standardized values of environmental data and daily stem radius variations and radial stem increments extracted from DMR were used, and the selected time period was similar to the period applied in correlation analyses. Environmental variables and daily stem radius changes and radial stem increments extracted from DMR were depicted as vectors, indicating (1) direction in which the value of the vector (i.e. environmental variables and variables extracted from DMR) increases and (2) correlations among vectors and component axes, whereby low angles among vectors and between vectors and component axes correspond to high correlations.

\section{Microclimate records}

During the study period, air temperature, $\mathrm{RH}$ and daily precipitation were collected automatically (ONSET, Pocasset, MA, USA) above canopy at top of a scaffold at c. 18-m height. Measuring intervals for all sensors were $30 \mathrm{~min}$, and mean daily air temperatures were calculated by averaging all measurements (48 values per day). VPD in the air was calculated from the hourly means of air temperature and relative humidity using the equation given in Prenger and Ling (2000). Volumetric SWC in 5-10 and 15-20 cm soil depth (three sensors per depth) was recorded within the study plot (ThetaProbes Type ML2x, Delta-T, Cambridge, England). Additionally, soil temperature in the top $5-10 \mathrm{~cm}$ soil depth (three sensors) was measured (HOBO, ONSET, Pocasset, MA, USA). Measuring intervals were set to $60 \mathrm{~min}$, and mean daily water content (vol\%) and soil temperature $\left({ }^{\circ} \mathrm{C}\right)$ were calculated by averaging all measurements from three sensors.

Environmental variables during growing seasons 2011 and 2012

Climate in 2011 and 2012 distinctly deviated at the start of the growing season in spring. Mean daily air temperatures in April and May were 3.2 and $0.6{ }^{\circ} \mathrm{C}$ higher in 2011 compared to 2012 (Table 1). Furthermore, an almost continuous drought period lasted from 19 March to 13 May 2011 (Fig. 1a, b), which caused SWC at the study plot to drop to c. 5 vol\% in early May. Starting with rainfall events in mid-May 2011, SWC reached 20-30 vol\% until mid-August, when low rainfall caused a decrease in SWC to $c .10 \mathrm{vol} \%$ for several weeks. In 2012, frequent rainfall events in March and April caused high SWC (c. 25 vol\%) until May, when SWC temporarily dropped to $10 \mathrm{vol} \%$ due to low rainfall and strongly increasing temperature (Fig. 1c, d). The observed abrupt fluctuations in SWC following precipitation events are caused by low waterholding capacity of the shallow, stony soils. Air temperature and rainfall during summer 2012 exceeded records in 2011 by $1.2{ }^{\circ} \mathrm{C}$ and $86 \mathrm{~mm}$, respectively (Table 1). Daily mean soil temperature in $5-10 \mathrm{~cm}$ soil depth generally followed trend in air temperature, but showed minor amplitudes (Fig. 1; Table 1).

\section{Results}

Dynamics of tracheid formation and radial stem growth

The dormant cambium consisted of 5-6 cells in P. sylvestris and $L$. decidua, when there was no cambial activity from July through March (Fig. 2a, b). In P. abies, 6-7 cambial cells were developed during the dormant period lasting from August through March. During both growing seasons, the number of cambial cells reached highest values in P. abies amounting to 12 cells in June 2011. While cambial activity in P. sylvestris peaked in late April 2011 and early May 2012, a persistent cambial activity from May through June can be deduced in L. decidua and $P$. abies during both study years. In 2011, onset of tracheid formation, i.e. detection of first enlarging cells, occurred in early April (100 doy) in P. sylvestris and in mid-April (111 doy) in P. abies and L. decidua (Fig. 2c, d; Table 2). In all species, onset of tracheid formation was significantly 
Table 1 April, May and summer (June-August) mean daily air and soil temperature and precipitation sum during 2011 and 2012 growing seasons recorded within the study area

\begin{tabular}{|c|c|c|c|c|c|c|}
\hline & \multicolumn{2}{|c|}{ Air temperature $\left({ }^{\circ} \mathrm{C}\right)$} & \multicolumn{2}{|c|}{ Soil temperature $\left({ }^{\circ} \mathrm{C}\right)$} & \multicolumn{2}{|c|}{ Precipitation (mm) } \\
\hline & 2011 & 2012 & 2011 & 2012 & 2011 & 2012 \\
\hline April & $11.5 \pm 3.2$ & $8.3 \pm 4.4$ & $8.0 \pm 0.9$ & $6.8 \pm 1.3$ & 4 & 43 \\
\hline May & $14.2 \pm 3.6$ & $13.6 \pm 3.6$ & $10.5 \pm 1.5$ & $10.3 \pm 1.2$ & 72 & 40 \\
\hline Summer & $16.5 \pm 3.5$ & $17.7 \pm 3.3$ & $14.4 \pm 1.5$ & $15.1 \pm 1.6$ & 278 & 364 \\
\hline
\end{tabular}

Mean values \pm standard deviation are shown
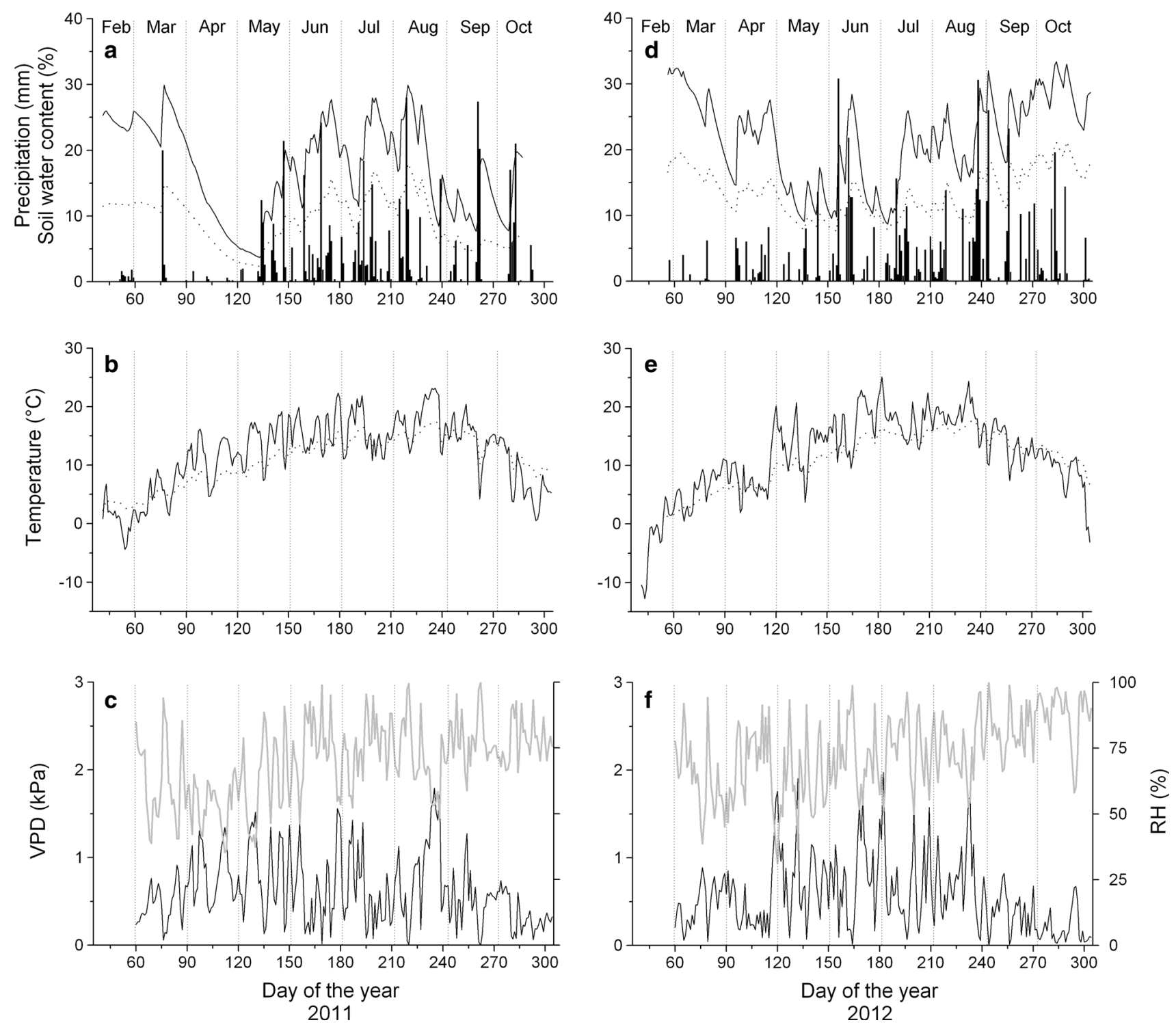

Fig. 1 Climate variables, SWC (vol\%) and soil temperature recorded during the growing seasons 2011 and 2012 within the study plot. a, d Daily precipitation sum (bars) and SWC at $5-10 \mathrm{~cm}$ (solid line) and $10-15 \mathrm{~cm}$ soil depth (dashed line). b, e Mean daily air (solid line) and

soil temperature (dashed line) recorded within the stand at $2 \mathrm{~m}$ height and in 5-10 $\mathrm{cm}$ soil depth, respectively. c, f Vapour pressure deficit (VPD, solid line) and relative air humidity $(\mathrm{RH}$, grey line $)$

delayed by c. 2 weeks in 2012 compared to 2011 . Enlarging cells assumed to indicate radial stem growth were detected until early August and late-September in

2011 and end of August and mid-September in 2012. In $P$. sylvestris and $L$. decidua, tracheid formation ended 3-4 weeks earlier in 2011 than 2012 (Table 2), while in $P$. 
Fig. 2 Number of cells in the cambial zone (a-b) and in radial enlargement (c-d) during the growing seasons 2011 and 2012. Tracheid dynamics of different species are denoted by open circles ( $P$. abies), filled circles (P. sylvestris) and open triangles (L. decidua). Bars represent standard deviations
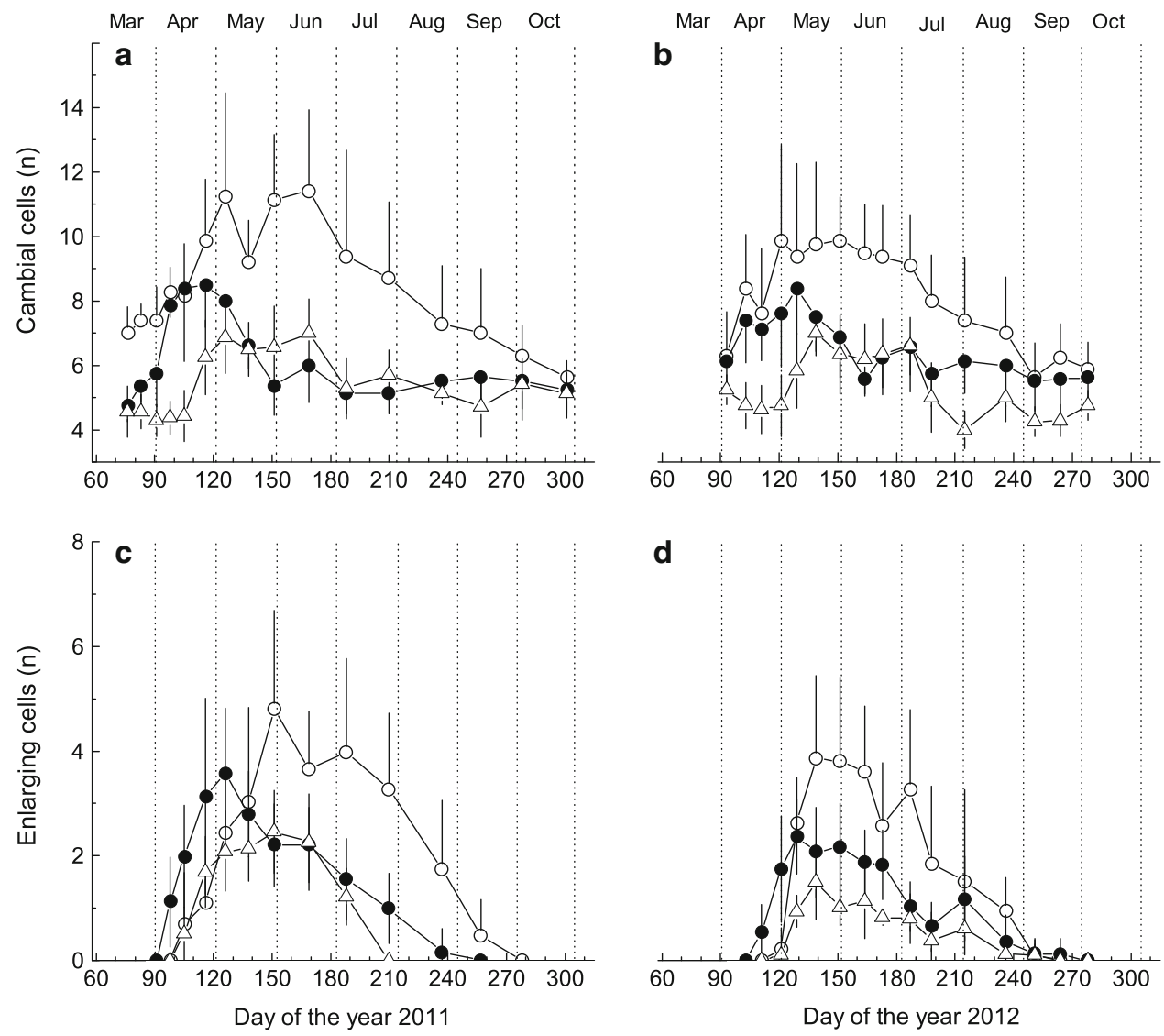

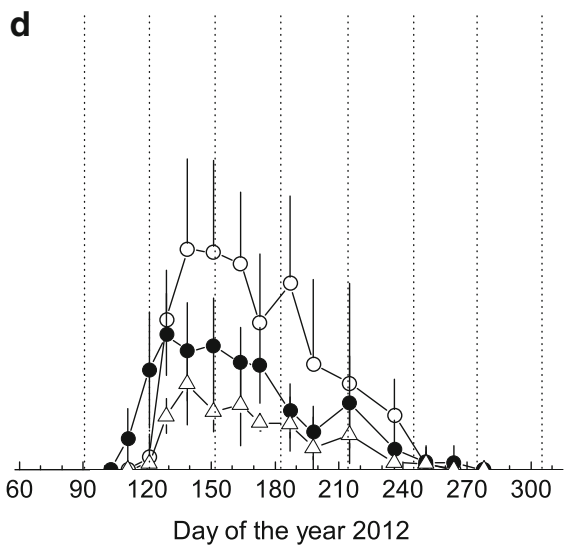

Table 2 Onset, end and duration of tracheid formation (TF) in P. sylvestris, P. abies and L. decidua in 2011 and 2012 ( $n=5-8$ trees/species)

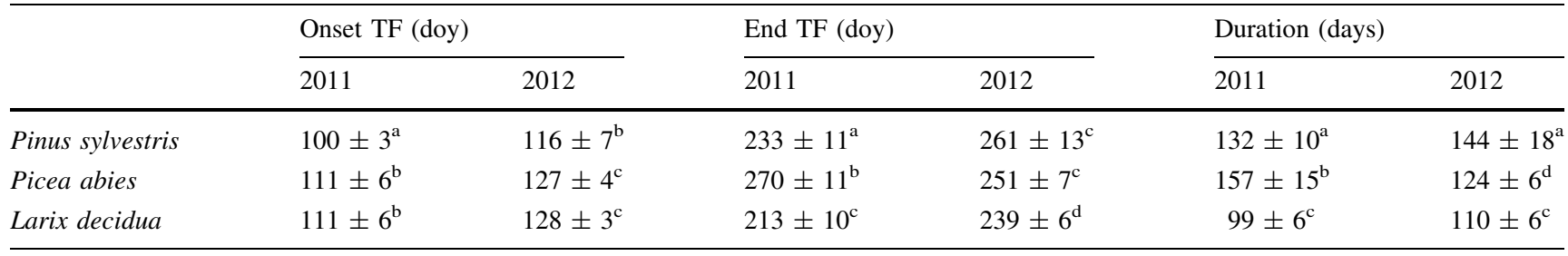

Timing of tracheid formation is given in days of the year (doy; mean values \pm standard deviation). Statistically significant differences of mean values between species (independent samples) and years (dependent samples) are indicated by different letters $(P \leq 0.05$; Student's $t$ test)

abies, end of tracheid formation occurred c. 3 weeks later in 2011 than 2012. In both years, duration of tracheid formation was significantly different among species, whereby $L$. decidua showed lowest durations amounting to less than 4 months.

Dendrometer traces depicted in Fig. 3a, d were set to zero at the day of the year, when first row of enlarging cells was detected (for details see "Materials and methods"). Quite synchronous diurnal cycles of stem shrinking and swelling were found in all species (data not shown), whereby during the period April through September 2011 and 2012, stem radius reached maximum values in the morning (c. 8 a.m. in P. sylvestris and c. 9 a.m. in P. abies and $L$. decidua) and minimum values in late afternoon (c. 6 p.m. in $P$. abies and $P$. sylvestris and $c .7$ p.m. in $L$. decidua). The Gompertz function adequately fitted intra- annual growth producing $R^{2}$ ranging between 0.670 and 0.962 (mean $0.887 \pm 0.12$; Table 3). In 2011 and 2012, maximum daily radial growth peaked around 24 May (c. 144 doy) and 6 June (c. 158 doy), respectively, in all species. The upper asymptote of the Gompertz function, which corresponds to total annual increment, reached lowest and highest values for $L$. decidua and P. abies, respectively (Table 3). Amplitudes of daily radial change (Fig. 3b, e) and extracted radial stem increment (Fig. 3c, f) were highest in $P$. abies and lowest in L. decidua.

Relationship of stem radius change to environmental factors

As depicted in Fig. 4a-c, daily radius change of all species showed quite similar response to environmental factors. 
Fig. 3 Time series of mean daily DMR modelled by applying the Gompertz function $(\mathbf{a}, \mathbf{d}$; for parameters see Table 3), daily radial change (b, e), extracted radial increment and daily increment calculated on the basis of modelled growth (c, f; solid and dashed lines, respectively). Species are denoted by solid line (P. abies), dark grey line ( $P$. sylvestris) and light grey line (L. decidua). Bars in a and $\mathbf{d}$ represent standard deviations among $\operatorname{DMR}(n=6)$
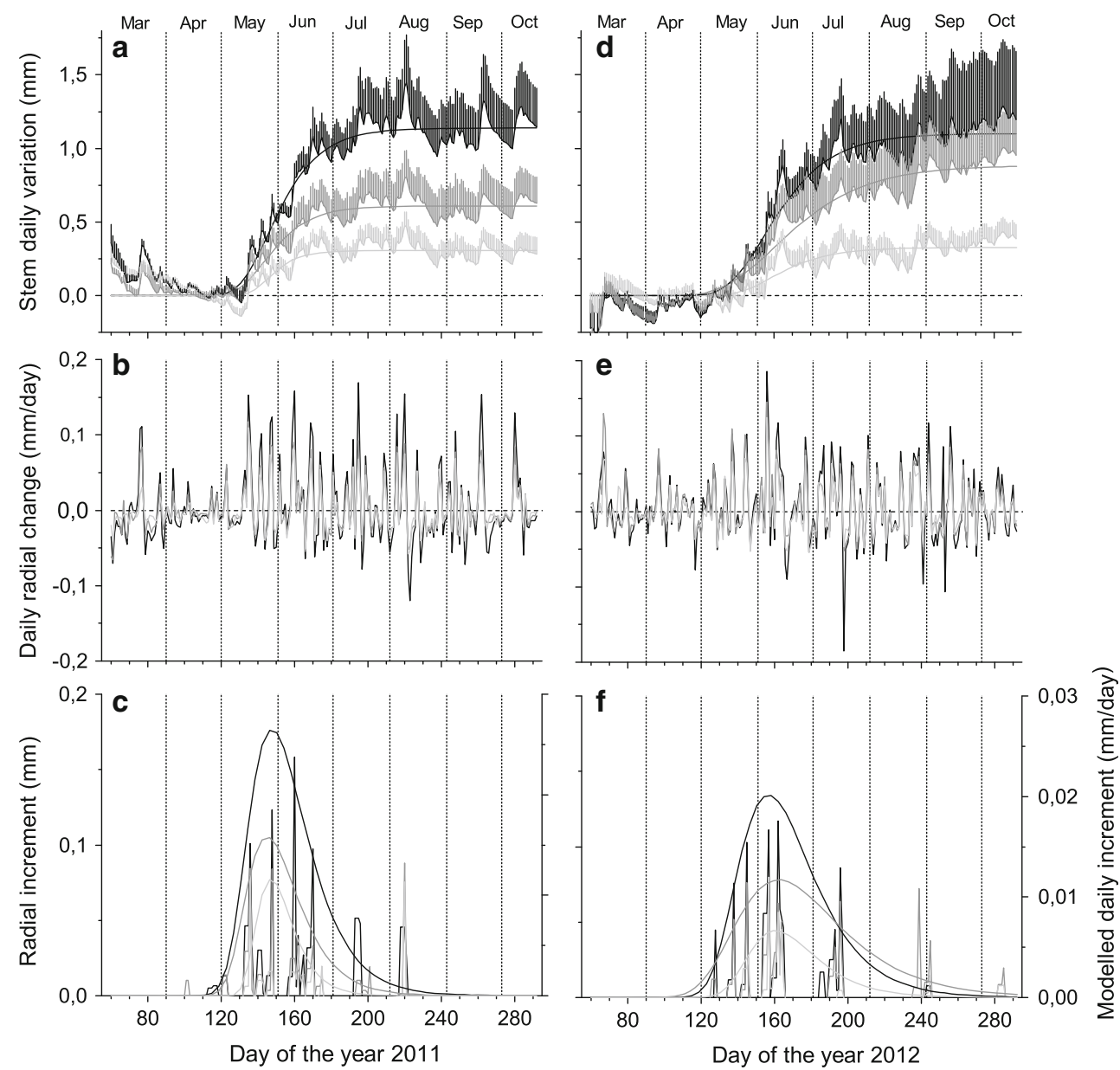

Table 3 Parameters of the Gompertz function for intra-annual radial growth in 2011 and 2012 (see Fig. 3a, d) of P. sylvestris, P. abies and L. decidua and $R^{2}$ of the model

\begin{tabular}{|c|c|c|c|c|c|}
\hline Species & Year & $A(\mu \mathrm{m})$ & $I_{p}(\mathrm{doy})$ & $\kappa$ & $R^{2}$ \\
\hline \multirow[t]{2}{*}{ Pinus sylvestris } & 2011 & $609 \pm 7$ & $143 \pm 0.9$ & $0.071 \pm 0.006$ & 0.934 \\
\hline & 2012 & $885 \pm 14$ & $160 \pm 1.3$ & $0.036 \pm 0.002$ & 0.948 \\
\hline \multirow[t]{2}{*}{ Picea abies } & 2011 & $1,138 \pm 12$ & $146 \pm 0.8$ & $0.064 \pm 0.004$ & 0.947 \\
\hline & 2012 & $1,101 \pm 13$ & $155 \pm 0.9$ & $0.050 \pm 0.003$ & 0.962 \\
\hline \multirow[t]{2}{*}{ Larix decidua } & 2011 & $306 \pm 8$ & $145 \pm 1.7$ & $0.104 \pm 0.023$ & 0.670 \\
\hline & 2012 & $326 \pm 7$ & $159 \pm 1.8$ & $0.056 \pm 0.007$ & 0.858 \\
\hline
\end{tabular}

$\mathrm{A}=$ upper asymptote, $\mathrm{I}_{\mathrm{p}}=$ inflection point, doy $=$ day of the year, $\kappa=$ rate of change parameter, mean values \pm standard deviation

Closest direct correlations were found with $\mathrm{RH}$ (mean $r=0.789, p<0.001$ ) and precipitation (mean $\tau=0.545$, $p<0.001)$. Highly significant indirect relationships were also observed with VPD and air temperature (mean $r=$ -0.769 and -0.679 , respectively). Lower negative coefficients were found between daily radius change and soil temperature, and coefficients of SWC (for both soil depths) were not significant for all species (Fig. 4 and data not shown). Relationships between stem radial increments extracted from DMR and environmental variables are shown in Fig. 5a-c. Among species, stem radial increment of $P$. abies was most closely related to RH $(r=0.636$, $p<0.001)$ and precipitation $(\tau=0.541, \quad p<0.001)$. Lower but statistically significant coefficients between radial stem increment and $\mathrm{RH}$ and precipitation ( $r=0.596, p<0.01$ and $\tau=0.337, p<0.05$, respectively) were also found for P. sylvestris. For L. decidua, corresponding correlation coefficients for air humidity and precipitation were lowest and amounted to 0.471 $(p<0.05)$ and $0.171(p>0.05)$, respectively. VPD and air temperature were inversely related to radial stem increment in all species, whereby highest and lowest coefficients were 

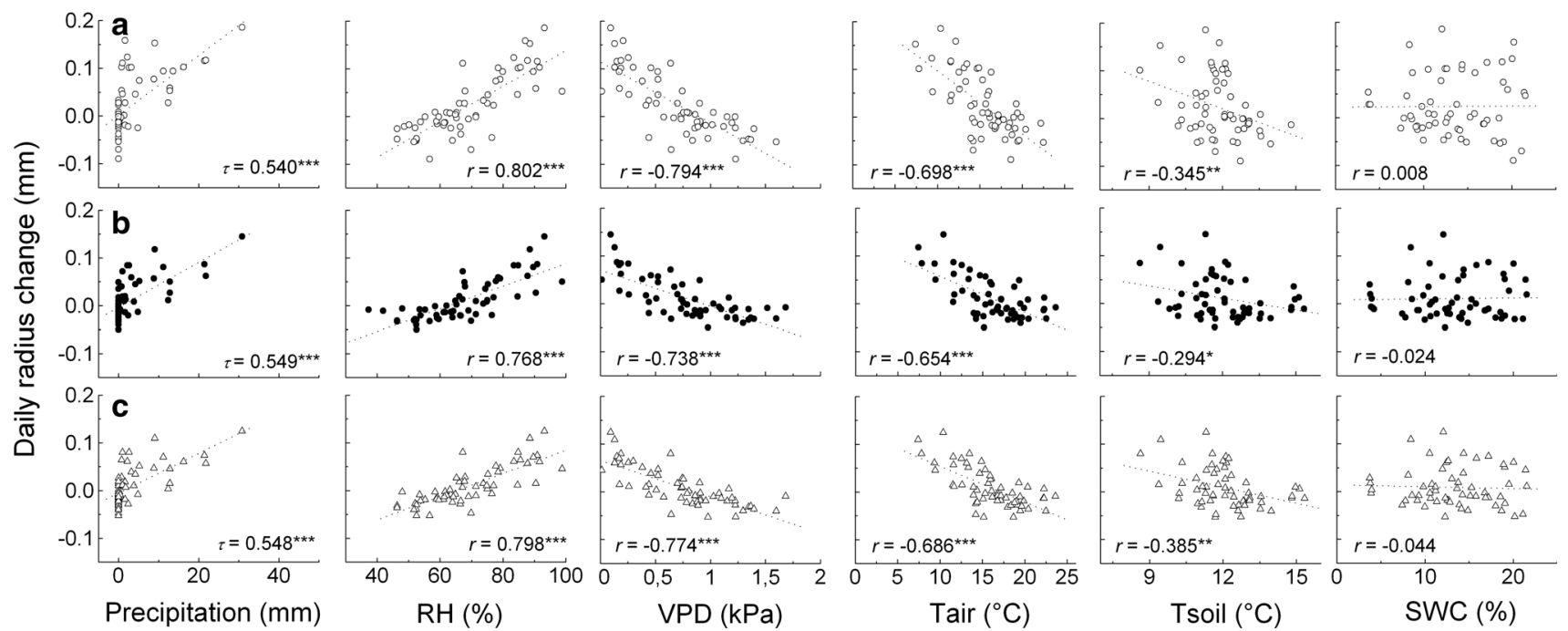

Fig. 4 Correlations between daily radius change of P. abies (a, open circles), P. sylvestris (b, filled circles) and L. decidua (c, triangles) and environmental factors (precipitation, relative air humidity $(\mathrm{RH})$, vapour pressure deficit (VPD), air temperature (Tair), soil temperature
(Tsoil), SWC in 5-10 cm soil depth (SWC)). Pearson's correlation coefficient $(r)$ and Kendall's tau coefficient $(\tau)$ were calculated ( $n=58$; for details see "Materials and methods"). *** $p<0.001$; $* * p<0.01 ; * p<0.05$
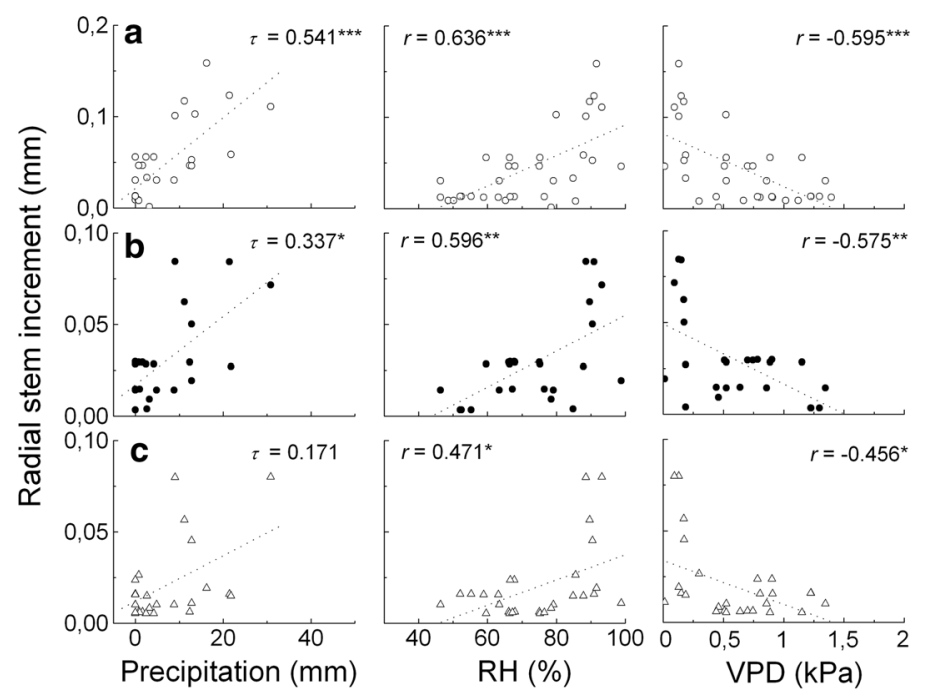

Fig. 5 Correlations between radial stem increment of P. abies (a, open circles), P. sylvestris (b, filled circles) and L. decidua (c, triangles) and environmental factors abbreviation of environmental factors as in Fig. 4. A one-day lag in radial stem increment was

found in P. abies and L. decidua, respectively. Edaphic factors (soil temperature and SWC) showed no significant relationship to radial stem increment in all species.

The first principal component (PC1) of the PCA considering all environmental factors and growth parameters extracted from DMR explained $55.6 \%$ of the variability (Fig. 6), whereby climatic and edaphic factors spread along PC1 and PC2, respectively. Because low angles between vectors correspond to high correlations, it can be deduced

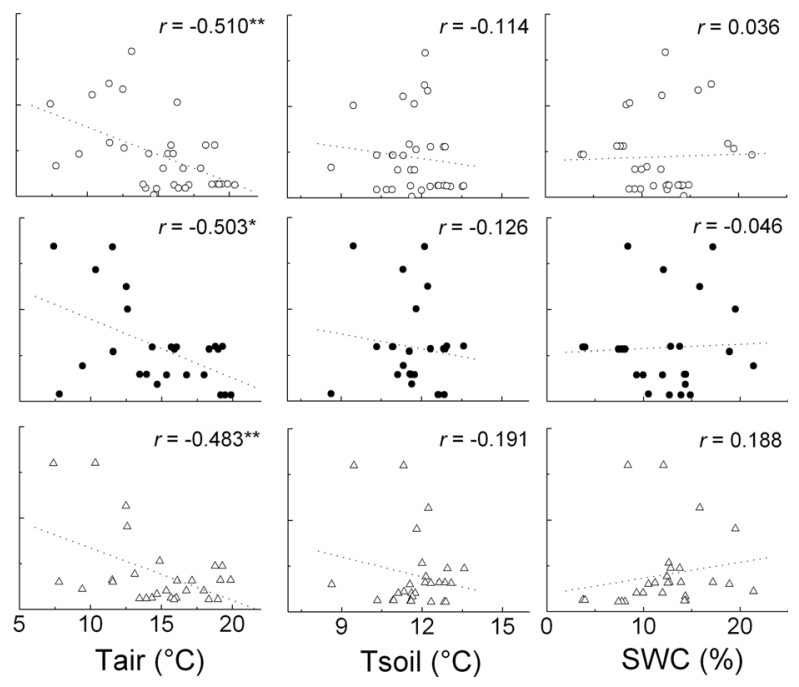

considered in all correlations. Pearson's correlation coefficient $(r)$ and Kendall's tau coefficient $(\tau)$ were calculated ( $n=33,25$ and 28 for $P$. abies, $P$. sylvestris and $L$. decidua, respectively; for details see "Materials and methods"). ***p $<0.001 ; * * p<0.01 ; * p<0.05$

that daily radius change of all species is more closely related to climatic factors than radial stem increment (direct relationship with precipitation and $\mathrm{RH}$ and inverse relationship with VPD and air temperature). Furthermore, because edaphic factors spread along PC2 explaining only a small percentage of variability (15.1\%), their influence on growth parameters is regarded to be marginal. In summary, the PCA analysis confirmed results of correlation analysis on a multivariate level (Fig. 6). 


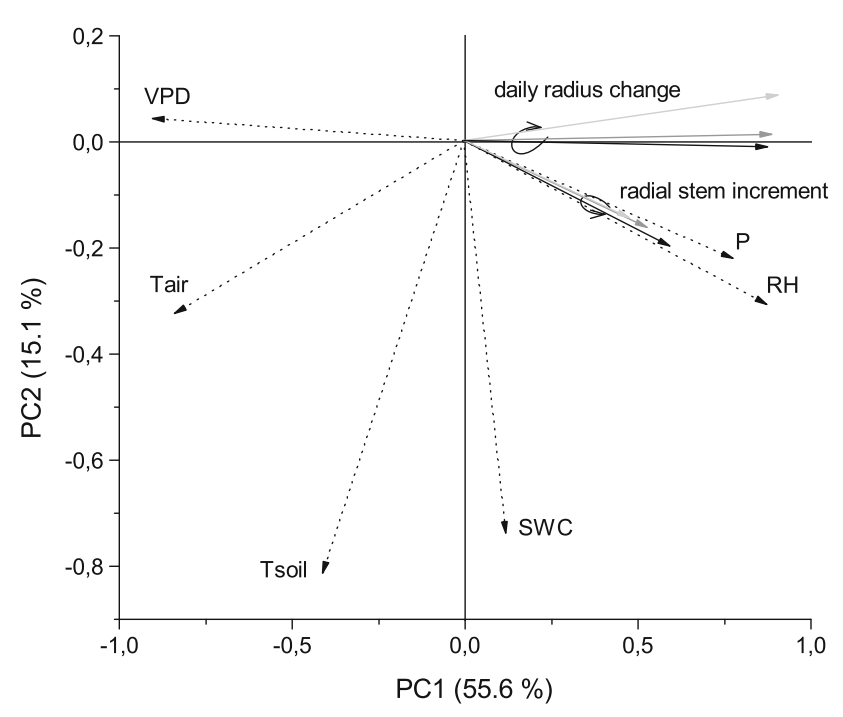

Fig. 6 Principal component analysis of environmental factors and daily radius change and radial stem increment of P. abies (solid line), $P$. sylvestris (dark grey line) and L. decidua (light grey line). Abbreviation of environmental factors as in Fig. 4

\section{Discussion}

Climate factors related to growth resumption and cessation

It is well known that bud break and growth onset after winter dormancy in temperate and boreal trees are highly responsive to temperature (for a review see Körner 2006; Hänninen and Tanino 2011; Rossi et al. 2011). Therefore, significantly earlier onset of tracheid formation by c. 2 weeks in 2011 compared to 2012 in all species is related to strikingly warmer temperature prevailing at the start of the growing season in 2011. Artificial heating of stems of evergreen conifers was also found to induce reactivation of the cambium during the quiescent stage indicating that cambium activity is highly responsive to temperature (Oribe et al. 2001; Gričar et al. 2006). Similarly, in several studies on temporal dynamics of wood formation, warm spring temperatures were reported to result in earlier onset of cambial activity and xylem cell differentiation (Rossi et al. 2007; Deslauriers et al. 2008; Gruber et al. 2009; Swidrak et al. 2011). That enlargement of tracheids in April and May 2011 occurred during an extensive drought period indicates that conifers can draw upon water reserves stored in sapwood and bark (cf. Holbrook 1995; Grip and Hällgren 2005). Significantly, earlier onset of cambial activity in $P$. sylvestris compared to $P$. abies and L. decidua in both study years might be due to existence of species-specific temperature (Begum et al. 2013) and/or photoperiod thresholds (Körner and Basler 2010).

Within the study area and in other drought-prone areas, it was found that water deficits during summer cause early cessation of cambial activity in conifers (Pichler and Oberhuber 2007; Levanič et al. 2009; Thabeet et al. 2009). Therefore, significantly delayed ending of xylem formation in 2012 compared to 2011 in early successional species $(P$. sylvestris and L. decidua) can be related to higher amount of precipitation occurring during summer 2012. In accordance with findings of Cuny et al. (2012) that late-successional species utilize resources more efficiently, latesuccessional $P$. abies developed largest radial increments in both study years. Because SWC throughout the growing season was found to be constantly higher close to the soil surface than in deeper soil layers, it can be deduced that $P$. abies is highly adapted to absorb scattered low rainfall events prevailing within the study area. This reasoning is supported by findings that fine roots of $P$. abies are distributed primarily in upper soil layers (Schmid and Kazda 2002) and $P$. abies is the only tree species within the study area which shows scattered regeneration in closed stands (Schuster and Oberhuber 2013b). Hence, we suggest that shallow rooting and shade tolerance provide $P$. abies a competitive advantage over more drought-tolerant $P$. sylvestris, until increase in intertree competition for water in dense stands exceeds physiological thresholds for drought resistance. Strikingly, low annual increments detected in $L$. decidua corroborate findings of Eilmann and Rigling (2012) that L. decidua is maladjusted to dry conditions, which is possibly related to its deciduous habit and/or anisohydric strategy, i.e. high transpiration rates are maintained under drought (Leo et al. 2013) causing finally impairment of tree water status (Bréda et al. 2006).

In both study years, duration of tracheid formation was significantly different among species and a significantly earlier onset of radial growth in $P$. sylvestris and earlier growth cessation in L. decidua compared to other cooccurring species was detected. These findings corroborate the hypothesis that different climate-growth relationships found in a dendroclimatological study by Schuster and Oberhuber (2013a) are caused by a temporal shift in wood formation among species.

Timing of maximum radial stem growth

Cuny et al. (2012) reported that in a temperate-mixed coniferous forest in France, the maximal rate of wood formation in A. alba, $P$. abies and $P$. sylvestris occurred at the same time for all species in early June. Due to more extreme environmental conditions prevailing within our study area and selected coniferous species possess varying drought sensitivity (Ellenberg and Leuschner 2010; Eilmann and Rigling 2012), different timing of maximum radial growth was expected to occur. However, we also found quite synchronous maximum radial stem growth in all species and in both study years indicating that a close 
environmental and/or endogenous control of intra-annual radial stem growth of conifers in mixed stands exists. In accordance with previous findings (Oberhuber and Gruber 2010), radial growth in both years peaked several weeks before summer solstice [around 24 May (144 doy) and 6 June (158 doy) in 2011 and 2012, respectively] indicating that a photoperiodic growth constraint, which was suggested to affect radial growth of conifers at the Alpine treeline and in boreal forests (Rossi et al. 2006b) is implausible for coniferous trees growing at low elevation sites.

Previously, Gruber et al. (2010) suggested that early achievement of maximum growth rate in $P$. sylvestris is an adaptation to cope with extreme environmental conditions prevailing within the study area, i.e. recurring drought periods in spring combined with limited water-holding capacity and nutrient deficiency of shallow, stony soils. These environmental conditions might require an early switch of carbon allocation to belowground organs and mycorrhiza (Nehls et al. 2007) including necessity to defend against biotic stress to sustain tree physiology and resist attack by pathogens (McDowell et al. 2008). However, because the temporal shift in timing of maximum growth among study years is in accordance with shift in growth onset, results corroborate hypothesis raised by Rossi et al. (2012) that phenological phases involved in wood formation are closely interconnected, i.e. climate variables affecting onset of xylem formation after winter dormancy could indirectly trigger all successive phases of tree ring formation. Alternatively, timing of maximum radial growth might be influenced by temporal dynamics of needle and/or shoot growth, because almost $50 \%$ of the annual carbon gain is allocated to wood (Grote 1998; Oribe et al. 2003). This reasoning is supported by findings of Swidrak et al. (2013) that maximum radial growth in $L$. decidua and $P$. abies occurred several weeks after needle lengthening was completed.

\section{Environmental factors influencing intra-annual radial} growth

Daily stem radius variations represent a combination of water- and growth-induced radius expansion and occur mainly in the elastic tissues, i.e. cambium, phloem and subero-phellodermic layer (e.g. Deslauriers et al. 2007). The close lateral linkage of water conducting xylem with phloem translates changes in tree water status directly to shrinking and swelling of non-lignified tissues in the bark and phloem (Molz and Klepper 1973; Zweifel and Häsler 2001). Hence, the close correlations found among daily radius change and VPD, which reflects $\mathrm{RH}$ and air temperature and besides wind and radiation influences the rate of transpiration (Taiz and Zeiger 2010), can be attributed to changes in leaf transpiration. Because a close coupling of transpiration with xylem sap flow was reported by Steppe et al. (2006), missing significant relationships between SWC and growth parameters extracted from DMR of all species imply that transpiration draws upon water stored in the stem rather than soil water (e.g. Cermák et al. 2007; Betsch et al. 2011). This reasoning is supported by Zweifel et al. (2005), who found that at dry sites, transpired water is more strongly withdrawn from internal storage tissues than at moist sites. Considering that water uptake of trees within the rocky study area might also occur from deep cracks, results of our study indicate that actual plant water status can differ from soil water status determined in upper soil layers $(5-20 \mathrm{~cm}$ depth), which is consistent with reports from several authors (Hinckley et al. 1978; Oren and Pataki 2001). A similar decoupling between radial growth of $P$. sylvestris exposed to drought and actual soil water potential was reported by Zweifel et al. (2006). Based upon lagged response found between stem increment and environmental variables, we suggest that replenishment of usable stem water reservoir occurs within a few days after scattered rainfall events occur.

Statistically significant relationships found between precipitation and atmospheric water status (VPD) and extracted radial increments in all species might indicate improved tree water status due to a decrease in transpiration rates when VPD of the air was low, whereas high VPD causes reduction in cell turgor pressure inhibiting cell enlargement and growth (Major and Johnsen 2001; Zweifel et al. 2005; Steppe et al. 2006). Several studies also revealed that wetting of leaves positively affected plant water status without noticeably increasing soil wetness (Katz et al. 1989; Boucher et al. 1995; Burgess and Dawson 2004; Breshears et al. 2008). A close coupling of intra-annual radial stem growth to atmospheric water status was previously reported for $P$. sylvestris at xeric sites within the study area (Oberhuber and Gruber 2010), in temperate broad-leaved tree species (Köcher et al. 2012), and for Abies balsamea growing in the boreal forests of Canada (Deslauriers et al. 2003b). The importance of VPD for tree water status was also reported in an experimental study of tree-seedling mortality during drought by Will et al. (2013). That daily radial increments extracted from DMR of all species have been found to be more closely related to microclimate when a lag of one day is considered is attributed to delayed replenishment of internal water stores due to water uptake from deep crevices entailing a slow release of low stem water potential. Consistently, low coefficients found between stem increment of all species and precipitation support this reasoning.

Consistently, lower correlation coefficients observed between radial stem increment of $L$. decidua and climate variables might indicate difficulties in extracting radial stem increment from this slow-growing tree species (mean 
annual increment $c .0 .3 \mathrm{~mm}$ ), because the fraction of reversible stem swelling and shrinkage caused by diurnal changes in atmospheric conditions is higher when trees are growing slowly. That extracted radial stem increments of all species were not significantly related to soil temperature is in agreement with findings of Lupi et al. (2012), who reported that in the short term, a direct influence of soil temperature on stem growth does not exist. On the other hand, significant inverse relationships found between soil temperature and daily radius change in all species can be explained by a close relationship existing among air and soil temperature and the influence of air temperature on tree water status.

\section{Conclusions}

Results of our study provided an insight into environmental control of intra-annual radial growth of co-occurring coniferous trees exposed to drought. While in dendroclimatological studies conducted within the study area (e.g. Schuster and Oberhuber 2013a), precipitation and temperature (direct and inverse relationship, respectively) were found to control radial growth, at short timescale primarily moist atmospheric conditions rather than SWC or rainfall favoured radial stem growth. We suggest that reduced transpiration rates under conditions of low-evaporative demand (i.e. low VPD) improve tree water status, which affects cambial cell division and turgor-driven tracheid expansion in the stem. This reasoning is corroborated when considering that (1) resumption of aboveground growth after winter dormancy is unresponsive to soil water availability under drought stress (Swidrak et al. 2011; this study), and (2) during the main period of radial growth, SWC did not affect stem increment. Considering also temporal shift in wood formation detected among species, determining climate-growth responses of trees on short timescale is important to refine analyses gathered from long-term tree ring studies.

Acknowledgments This research was funded by the Austrian Science Fund (FWF), Project No. P22280-B16 "Conifer radial stem growth in response to drought". We thank Roman Schuster for excellent field research assistance.

Open Access This article is distributed under the terms of the Creative Commons Attribution License which permits any use, distribution, and reproduction in any medium, provided the original author(s) and the source are credited.

\section{References}

Anfodillo T, Rento S, Carraro V, Furlanetto L, Urbinati C, Carrer M (1998) Tree water relations and climatic variations at the alpine timberline: seasonal changes of sap flux and xylem water potential in Larix decidua Miller, Picea abies (L.) Karst. and Pinus cembra L. Ann For Sci 55:159-172

Begum S, Nakaba S, Yamagishi Y, Oribe Y, Funada R (2013) Regulation of cambial activity in relation to environmental conditions: understanding the role of temperature in wood formation of trees. Physiol Plant 147:46-54

Betsch P, Bonal D, Breda N, Montpied P, Peiffer M, Tuzet A, Granier A (2011) Drought effects on water relations in beech: the contribution of exchangeable water reservoirs. Agric For Meteorol 151:531-543

Boucher JF, Munson AD, Bernier PY (1995) Foliar absorption of dew influences shoot water potential and root-growth in Pinus strobus seedlings. Tree Physiol 15:819-823

Bouriaud O, Leban J-M, Bert D, Deleuze C (2005) Intra-annual variations in climate influence growth and wood density of Norway spruce. Tree Physiol 25:651-660

Bréda N, Huc R, Granier A, Dreyer E (2006) Temperate forest trees and stands under severe drought: a review of ecophysiological responses, adaptation processes and long-term consequences. Ann For Sci 63:625-644

Breshears DD, McDowell NG, Goddard KL, Dayem KE, Martens SN, Meyer CW, Brown KM (2008) Foliar absorption of intercepted rainfall improves woody plant water status most during drought. Ecology 89:41-47

Burgess SSO, Dawson TE (2004) The contribution of fog to the water relations of Sequoia sempervirens (D. Don): foliar uptake and prevention of dehydration. Plant Cell Environ 27:1023-1034

Čermák J, Kučera J, Bauerle WL, Phillips N, Hinckley TM (2007) Tree water storage and its diurnal dynamics related to sap flow and changes in stem volume in old-growth Douglas-fir trees. Tree Physiol 27:181-198

Cuny HE, Rathgeber CBK, Lebourgeois F, Fortin M, Fournier M (2012) Life strategies in intra-annual dynamics of wood formation: example of three conifer species in a temperate forest in north-east France. Tree Physiol 32:612-625

Daudet FA, Ameglio T, Cochard H, Archilla O, Lacointe A (2005) Experimental analysis of the role of water and carbon in tree stem diameter variations. J Exp Bot 56:135-144

Deslauriers A, Morin H (2005) Intra-annual tracheid production in balsam fir stems and the effect of meteorological variables. Trees 19:402-408

Deslauriers A, Morin H, Begin Y (2003a) Cellular phenology of annual ring formation of Abies balsamea in the Quebec boreal forest (Canada). Can J For Res 33:190-200

Deslauriers A, Morin H, Urbinati C, Carrer M (2003b) Daily weather response of balsam fir (Abies balsamea (L.) Mill.) stem radius increment from dendrometer analysis in the boreal forests of Québec (Canada). Trees 17:477-484

Deslauriers A, Rossi S, Anfodillo T (2007) Dendrometer and intraannual tree growth: what kind of information can be inferred? Dendrochronologia 25:113-124

Deslauriers A, Rossi S, Anfodillo T, Saracino A (2008) Cambial phenology, wood formation and temperature thresholds in two contrasting years at high altitude in southern Italy. Tree Physiol 28:863-871

Downes G, Beadle C, Worledge D (1999) Daily stem growth patterns in irrigated Eucalyptus globulus and E. nitens in relation to climate. Trees 14:102-111

Dünisch O, Bauch J (1994) Influence of soil substrate and drought on wood formation of spruce (Picea abies (L.) Karst.) under controlled conditions. Holzforschung 48:447-457

Eilmann B, Rigling A (2012) Tree-growth analyses to estimate tree species' drought tolerance. Tree Physiol 32:178-187

Ellenberg H, Leuschner C (2010) Vegetation Mitteleuropas mit den Alpen in ökologischer, dynamischer und historischer Sicht. Ulmer, Stuttgart 
FAO (2006) World reference base for soil resources, vol 103. FAO, World Soil Resources Reports, Rome

Fekedulegen D, Hicks RR Jr, Colbert JJ (2003) Influence of topographic aspect, precipitation and drought on radial growth of four major tree species in an Appalachian watershed. For Ecol Manag 177:409-425

Fritts HC (1976) Tree rings and climate. Academic Press, London

Gričar J, Zupančič M, Čufar K, Koch G, Schmitt U, Oven P (2006) Effect of local heating and cooling on cambial activity and cell differentiation in the stem of Norway spruce (Picea abies). Ann Bot 97:943-951

Grip H, Hällgren JE (2005) Water cycling in coniferous forest ecosystems. In: Andersson F (ed) Ecosystems of the world, vol 6., Coniferous forestsElsevier, Amsterdam, pp 385-426

Grote R (1998) Integrating dynamic morphological properties into forest growth modelling-II. Allocation and mortality. For Ecol Manag 111:193-210

Gruber A, Zimmermann J, Wieser G, Oberhuber W (2009) Effects of climate variables on intra-annual stem radial increment in Pinus cembra (L.) along the alpine treeline ecotone. Ann For Sci 66:503. doi:10.1051/forest/2009038

Gruber A, Strobl S, Veit B, Oberhuber W (2010) Impact of drought on the temporal dynamics of wood formation in Pinus sylvestris. Tree Physiol 30:490-501

Hänninen H, Tanino K (2011) Tree seasonality in a warming climate. Trends Plant Sci 16:412-416

Herzog KM, Häsler R, Thum R (1995) Diurnal changes in the radius of a subalpine Norway spruce stem: their relation to the sap flow and their use to estimate transpiration. Trees 10:94-101

Hinckley TM, Lassoie JP, Running SW (1978) Temporal and spatial variations in the water status of forest trees. In: Ferrell WK (ed) Forest science monographs. Soc Am Foresters, Washington, DC

Holbrook NM (1995) Stem water storage. In: Gartner BL (ed) Plant stems: physiology and functional morphology. Academic Press, San Diego, pp 151-175

Hughes MK, Swetnam TW, Diaz HF (eds) (2011) Dendroclimatology. progress and prospects. Developments in paleoenvironmental research, vol 11. Springer, Dordrecht

Katz C, Oren R, Schulze E-D, Milburn JA (1989) Uptake of water and solutes through twigs of Picea abies (L.) Karst. Trees 3:33-37

Köcher P, Horna V, Leuschner C (2012) Environmental control of daily stem growth patterns in five temperate broad-leaved tree species. Tree Physiol 32:1021-1032

Körner C (2006) Significance of temperature in plant life. In: Morison JIL, Morecroft MD (eds) Plant growth and climate change. Blackwell, Oxford, pp 48-69

Körner C, Basler D (2010) Phenology under global warming. Science 327:1461-1462

Leo M, Oberhuber W, Schuster R, Grams TEE, Matyssek R, Wieser G (2013) Evaluating the effect of plant water availability on inner alpine coniferous trees based on sap flow measurements. Eur J For Res. doi:10.1007/s10342-013-0697-y

Levanič T, Gričar J, Gagen M, Jalkanen R, Loader NJ, McCarroll D, Oven P, Robertson I (2009) The climatic sensitivity of Norway spruce [Picea abies (L.) Karst.] in the southeastern European Alps. Trees 23:169-180

Linares JC, Camarero JJ, Carreira JA (2009) Plastic response of Abies pinsapo xylogenesis to drought and competition. Tree Physiol 29:1525-1536

Lupi C, Morin H, Deslauriers A, Rossi S (2012) Xylogenesis in black spruce: does soil temperature matter? Tree Physiol 32:74-82

Major JE, Johnsen KH (2001) Shoot water relations of mature black spruce families displaying a genotype $\mathrm{x}$ environment interaction in growth rate. III. Diurnal patterns as influenced by vapour pressure deficit and internal water status. Tree Physiol 21: $579-587$
McDowell N, Pockman WT, Allen CD, Breshears DD, Cobb N, Kolb T, Plaut J, Sperry J, West A, Williams DG, Yepez EA (2008) Mechanisms of plant survival and mortality during drought: why do some plants survive while others succumb to drought? New Phytol 178:719-739

Michelot A, Simard S, Rathgeber C, Dufrêne E, Damesin C (2012) Comparing the intra-annual wood formation of three European species (Fagus sylvatica, Quercus petraea and Pinus sylvestris) as related to leaf phenology and non-structural carbohydrate dynamics. Tree Physiol 32:1033-1043

Molz FJ, Klepper B (1973) On the mechanism of water-stress-induced stem deformation. Agron J 65:304-306

Nehls U, Grunze N, Willmann M, Reich M, Küster H (2007) Sugar for my honey: carbohydrate partitioning in ectomycorrhizal symbiosis. Phytochemistry 68:82-91

Oberhuber W, Gruber A (2010) Climatic influences on intra-annual stem radial increment of Pinus sylvestris (L.) exposed to drought. Trees 24:887-898

Oberhuber W, Kofler W (2000) Topographic influences on radial growth of Scots pine (Pinus sylvestris $\mathrm{L}$.) at small spatial scales. Plant Ecol 146:229-238

Oren R, Pataki DE (2001) Transpiration in response to variation in microclimate and soil moisture in southeastern deciduous forests. Oecologia 127:549-559

Oribe Y, Funada R, Shibagaki M, Kubo T (2001) Cambial reactivation in locally heated stems of the evergreen conifer Abies sachalinensis (Schmidt) Masters. Planta 212:684-691

Oribe Y, Funada R, Kubo T (2003) Relationships between cambial activity, cell differentiation and the localisation of starch in storage tissues around the cambium in locally heated stems of Abies sachalinensis (Schmidt) Masters. Trees 17:185-192

Orwig DA, Abrams MD (1997) Variation in radial growth responses to drought among species, site, and canopy strata. Trees 11:474-484

Pichler P, Oberhuber W (2007) Radial growth response of coniferous forest trees in an inner Alpine environment to heat-wave in 2003. For Ecol Manag 242:688-699

Plomion C, Leprovost G, Stokes A (2001) Wood formation in trees. Plant Physiol 127:1513-1523

Prenger JJ, Ling PP (2000) Greenhouse condensation control: Understanding and using vapour pressure deficit (VPD). Fact Sheet (Series) AEX-800. Ohio State University Extension. Columbus, $\mathrm{OH}$

Rossi S, Deslauriers A, Morin H (2003) Application of the Gompertz equation for the study of xylem cell development. Dendrochronologia 21:33-39

Rossi S, Anfodillo T, Menardi R (2006a) Trephor: a new tool for sampling microcores from tree stems. IAWA J 27:89-97

Rossi S, Deslauriers A, Anfodillo T, Morin H, Saracino A, Motta R, Borghetti M (2006b) Conifers in cold environments synchronize maximum growth rate of tree-ring formation with day length. New Phytol 170:301-310

Rossi S, Deslauriers A, Anfodillo T, Carraro V (2007) Evidence of threshold temperatures for xylogenesis in conifers at high altitudes. Oecologia 152:1-12

Rossi S, Morin H, Deslauriers A, Plourde PY (2011) Predicting xylem phenology in black spruce under climate warming. Glob Chang Biol 17:614-625

Rossi S, Morin H, Deslauriers A (2012) Causes and correlations in cambium phenology: towards an integrated framework of xylogenesis. J Exp Bot 63:2117-2126

Schmid I, Kazda M (2002) Root distribution of Norway spruce in monospecific and mixed stands on different soils. For Ecol Manag 159:37-47

Schuster R, Oberhuber W (2013a) Drought sensitivity of three cooccurring conifers within a dry inner Alpine environment. Trees 27:61-69 
Schuster R, Oberhuber W (2013b) Age-dependent climate-growth relationships and regeneration of Picea abies in a drought-prone mixed coniferous forest in the Alps. Can J For Res 43:599-608

Sheskin D (2007) Handbook of parametric and nonparametric statistical procedures, 4th edn. Chapman \& Hall/CRC, Boca Raton, FL

Steppe K, De Pauw DJW, Lemeur R, Vanrolleghem PA (2006) A mathematical model linking tree sap flow dynamics to daily stem diameter fluctuations and radial stem growth. Tree Physiol 26:257-273

Swidrak I, Gruber A, Kofler W, Oberhuber W (2011) Effects of environmental conditions on onset of xylem growth in Pinus sylvestris under drought. Tree Physiol 31:483-493

Swidrak I, Schuster R, Oberhuber W (2013) Comparing growth phenology of co-occurring deciduous and evergreen conifers exposed to drought. Flora. doi:10.1016/j.flora.2013.09.004

Taiz L, Zeiger E (2010) Plant physiology, 5th edn. Sinauer Associates, Sunderland, MA

Thabeet A, Vennetier M, Gadbin-Henry C, Denelle N, Roux M, Caraglio Y, Vila B (2009) Response of Pinus sylvestris L. to recent climatic events in the French Mediterranean region. Trees 23:843-853

Turcotte A, Morin H, Krause C, Deslauriers A, Thibeault-Martel M (2009) The timing of spring rehydration and its relation with the onset of wood formation in black spruce. Agr For Meteorol 149:1403-1409
Will RE, Wilson SM, Zou CB, Hennessey TC (2013) Increased vapour pressure deficit due to higher temperature leads to greater transpiration and faster mortality during drought for tree seedlings common to the forest-grassland ecotone. New Phytol. doi:10.1111/nph. 12321

Zeide B (1993) Analysis of growth equations. For Sci 39:594-616

Zhai L, Bergeron Y, Huang J-G, Berninger F (2012) Variation in intra-annual wood formation, and foliage and shoot development of three major Canadian boreal tree species. Am J Bot 99:827-837

Zweifel R, Häsler R (2000) Frost-induced reversible shrinkage of bark of mature subalpine conifers. Agr For Meteorol 102:213-222

Zweifel R, Häsler R (2001) Dynamics of water storage in mature subalpine Picea abies: temporal and spatial patterns of change in stem radius. Tree Physiol 21:561-569

Zweifel R, Item H, Häsler R (2000) Stem radius changes and their relation to stored water in stems of young Norway spruce trees. Trees 15:50-57

Zweifel R, Zimmermann L, Newbery DM (2005) Modeling tree water deficit from microclimate: an approach to quantifying drought stress. Tree Physiol 25:147-156

Zweifel R, Zimmermann L, Zeugin F, Newberry DM (2006) Intraannual radial growth and water relations of trees: implications towards a growth mechanism. J Exp Bot 57:1445-1459 